\title{
Efficacy of Ganoderma (Ganoderma lucidum ) Against Nephrotoxicity Induced by Cisplatin in Male Rats .
}

\author{
Maha M. Essam El-Din ${ }^{1}$ and Maha A. El-Mowafy ${ }^{2}$ \\ ${ }^{1}$ Department of Nutrition and Food Science, Faculty of Home Economics, Helwan \\ University, Cairo, Egypt. ${ }^{2}$ Dietitian, Directorate of Education, Gharbiyah, Egypt.
}

\begin{abstract}
In traditional Chinese medicine, ganoderma lucidum are widely used as medicine for a variety of diseases, such as chronic bronchitis inflammation, hyperlipidemia, hypertension, neurasthenia, hepatitis, leukopenia, and adjuvant treatment of cancer. The aim of this study was to evaluate its effect against cisplatin - induced nephrotoxicity in adult male albino rats. Forty five animals were classified into 5 groups 9 rats for each group. Group (1) fed on basal diet (negative group); groups (2 - 5) were injected with cisplatin ( $5 \mathrm{mg} / \mathrm{kg}$ body wt. ) intraperitoneuly to induce nephrotoxicity in rats ; group ( 2 ) fed on the basal diet as positive control group (+Ve); remained groups fed on the basal diet and supplemented with ganoderma lucidum at 5,10 and $15 \mathrm{~g} / \mathrm{kg}$ diet, respectively. Results revealed that positive control group had significant increase in serum levels of creatinine, urea, uric acid, urea nitrogen and total protein as well as Malondialdahyde ( $M O D$ ) but had significant decrease in serum levels of Superoxide Dismutase (SOD) , Catalase (CAT), Glutathione Peroxidase (GPX) and Glutathione (GSH) as compared to the negative control groups. While supplemented with different levels of ganoderma lucidum caused significant decreased in serum levels of creatinine, urea, uric acid, urea nitrogen and total protein as well as ( MOD ), but had significant increased in serum levels of (SOD) , (CAT), (GPX) and (GSH) as compared to the positive control group. From the present results it can be concluded that ganoderma lucidum feeding possess a therapeutic effect against cisplatin that induced nephrotoxicity in rats and inhibit oxidative stress. According to above results the consumption of ganoderma lucidum can be used to treat nephrotoxicity
\end{abstract}

Key words: Male albino rats, cisplatin, nephrotoxicity, Reishi mushrooms, Ganoderma lucidum, kidney function , antioxidant markers .

\section{Introduction}

The use of medicinal herbs is nowadays receiving an increasing attention all over the world due to their potential for health promotion and specific symptom management. Medicinal plants and herbs are used to initiate health healing through synergistic response unlike the specific properties of pharmaceuticals (Cohen et al .,2000; Zenk et al ., 2001 ). For over 4000 years Reishi mushrooms (Ganoderma Lucidum) have been recognized by Chinese medical professionals as a valuable remedy. Its Chinese name Lingzhi, means "spiritual potency". Reishi mushrooms are regarded by the Chinese as the "Medicine of Kings" they stated that the "long-term taking of Reishi (Lingzhi) will build a strong, healthy body and assure a long life (Wasson, 1968 and Lingzhi , 1986).

Ganoderma is a white root wood-degrading with hard fruiting bodies. The glycoprotein contains $10.1 \%$ of protein and 17 general amino acids and it is rich in glutamic acid, asparagic acid, alanine, glycine, threonine, and serine. It was 


\section{Maha M. Essam El-Din and Maha A. El-Mowafy}

mainly composed of mannose, galactose and glucose. In traditional Chinese medicine, ganoderma lucidum are widely used as medicine for a variety of diseases, such as chronic bronchitis, inflammation, hyperlipidemia, hypertension, neurasthenia, hepatitis, leukopenia, and adjuvant treatment of cancer ( Stavinoha , 1990 ; Jong and Birmingham ,1992 ; Bojana et al ., 2007 and Zhaoli et al., 2014) . In addition (Kenneth ,1992 ; Stanislaus ,1995 and Fernández-Rojas et al., 2014 ) found that Reishi contains natural substances called "triterpenes" which lowers high blood pressure, lowers cholesterol, and inhibits platelet aggregation which may lead to heart attacks and other circulation problems.

Cisplatinum (II) diamine dichloride (cisplatin) is extensively used for the management of oncological disorders, particularly of the ovary, testis, bladder, head and neck (Hamers et al ., 1991). Although higher doses of cisplatin are more efficacious for cancer chemotherapy, the high-dose therapy manifests toxicities such as nephrotoxicity (Bodenner et al., 1986 and Fernández-Rojas et al., 2014 ). A number of chemotherapeutic agents have been reported to render protection against cisplatin-induced nephrotoxicity. However, none of them is known to be clinically effective as a complete protective agent. Several lines of evidence indicated that free radicals are involved in the nephrotoxicity caused by cisplatin, and the damage is suggested to be the consequence of decreased renal antioxidant enzyme activity with enhanced lipid peroxidation. However, administration of antioxidants has been shown to ameliorate cisplatin-induced nephrotoxicity in animals (Babu et al ., 1995 ; Sheena et al .,2003 and Fernández-Rojas et al., 2014).

In the present study, we investigate the effects of ganoderma ( ganoderma lucidum ) against cisplatin-induced nephrotoxicity in rats .

\section{Material and Methods}

Materials :

Starch, cellulose, vitamin mixture and minerals were purchased from the El-Gomhoria Company Cairo - Egypt , and cisplatin were purchased from local pharmacy Cairo- Egypt. Ganoderma lucidum were purchased from DXN Saudi Arabia company, as powder and used as it's .

Experimental animals; adult male albino rats of Sprague-Dawley strain were obtained from Helwan station, Cairo, Egypt.

\section{Methods :}

This study was carried out on forty five albino male rats of Sprague-Dawley strain weighing $200-210 \mathrm{~g}$. Rats were kept in clean cages at 20-24 C temperature, 12 hour light / 12 hour dark cycle. All rats were fed and drinking water ad libitum. Rats were observed daily weighed twice weekly, feed intake was weighted daily and feed efficiency ratio were calculated.

All rats were fed the basal diet for one week before starting the experiment for acclimatization, as described by (Reeves et al.,1993). It consists of casien $20 \%$, corn oil $10 \%$, fibers $5 \%$, salt mixture $4 \%$, vitamin mixture $1 \%$, choline chloride $0.2 \%$ and the remainder is corn starch. After the acclimatization period, the rats groups were randomly divided into five equal groups $(n=9)$ as follow :

The first group $(n=9)$ : was fed on the basal diet to eat as negative control group $(-V e)$.

The second group $(n=36)$ : was fed on the basal diet and injected with cisplatin ( $5 \mathrm{mg} / \mathrm{kg}$ body wt. intraperitoneuly to induce nephrotoxicity in rats (Babu et al., 1995 and Sheena et al ., 2003). This group was divided into four sub-groups ( $n=9$ rats/ each ) as follow :

Group ( 1 ): was fed on the basal diet as positive control group (+Ve).

Group ( 2 ): was fed on the basal diet supplemented with $5 \mathrm{~g}$ ganoderma lucidum / $\mathrm{kg}$ diet

Group ( 3 ): was fed on the basal diet supplemented with $10 \mathrm{~g}$ ganoderma lucidum / $\mathrm{kg}$ diet 


\section{Egypt. J. of Nutrition and Health Vol. 9 No. 1 (2014)}

Group ( 4 ): was fed on the basal diet supplemented with $15 \mathrm{~g}$ ganoderma lucidum / $\mathrm{kg}$ diet

The ganoderma lucidum were added as replaced for equal amount of starch in the diet to maintain the percentage of other nutrient. Rats were kept for four weeks on the previous experimental diets and then animals were fasted overnight and sacrificed using diethyl ether for collecting blood and organs ( kidneys, heart and liver ).

\section{Blood Samples Collection :}

About 7-ml blood was withdrawn from the hepatic portal vein into clean dry centrifuge plastic tubes. Blood samples were centrifuged and sera were obtained in a clean well-stoppered vials then stored at $-20^{\circ} \mathrm{C}$ until chemical analysis.

\section{Biochemical analysis:}

Serum creatinine and urea were estimated by the method of (Brod and Sirota 1980 ; Marshell et al., 1980) , respectively. The blood urea nitrogen, serum uric acid levels and total proteins concentrations were measured using methods described by Henry et al., (1957); The activity of superoxide dismutase (SOD) was assayed by the method of (McCord and Fridovich, 1969), catalase (CAT) by the method of (Beers and Sizer 1952), glutathione peroxidase (GPX) by the method of (Hafemann et al ., 1974), levels of glutathione (GSH) by the method of (Moron et al., 1979) and malondialdehyde (MDA) by the method of (Ohkawa et al., 1979) .

\section{Biological evaluation :}

Calculation of organ relative weight was calculated according to the following equation:

Organ relative weight $=($ Organ weight $/$ Animal final weight $) \times 100$

Determination of body weight gain ( BWG) and feed efficiency ratio in rats were calculated at the end of the experimental period according to the following equations :

BWG $(\mathrm{g})=$ Final weight $(\mathrm{g})$-Initial weight $(\mathrm{g}) /$ Initial weight $(\mathrm{g})$.

FER $=$ Weight gain $(\mathrm{g}) /$ Feed intake $(\mathrm{g})$.

\section{Chemicals and Stains for Histopathological Examination:}

Chemicals such as saturated formaldehyde solution $40 \%$, sodium phosphate monobasic, sodium phosphate dibasic, Ethylene Diamine Tetra-acetic Acid ( EDTA) for decalcification and haematoxyline and eosine stain were obtained from Faculty of Veterinary Medicine, Cairo University, for histopathological examination of livers and kidneys .

\section{Statistical analysis:}

Statistical analysis of the collected data was carried out using SAS (version 9.0). Results were expressed as mean \pm SD. One way analysis of variance (ANOVA) was used. The differences among means were tested for significance using the high significant difference test (HSD) at $\mathrm{P} \leq 0.05$ according to $S A S$ ( 2006).

\section{Results and discussion.}

Effect of feeding on different concentration of ganoderma on body weight gain, feed intake, and feed efficiency ratio in nephrotoxicity rats.

Data in table ( 1 ) show that, positive control group had significant decrease in feed intake, body weight gain and feed efficiency ratio comparing with rats fed on basal diet (negative control). Moreover, rats injected with cisplatin to induce nephrotoxicity and supplemented with different levels of ganoderma powder ( 5,10 and $15 \mathrm{~g} / \mathrm{kg}$ diet $)$ had significant increase in feed intake, body weight gain and feed efficiency ratio when compared with positive control group. 


\section{Maha M. Essam El-Din and Maha A. El-Mowafy}

The present results are strongly supported by another study (Fenglin Li , 2011) who, found that consumption of ganoderma for 28 days had increased the body weight.

Data in Table ( 2 ) indicate that a significant decrease of organs relative weight, ( liver and heart) as compared with the positive control in all experimental groups with administered cisplatin, Furthermore kidney weight recorded non significant increase for all nephrotoxic rats compared with the positive control group.

Table ( 3 ) shows that positive control group had significant increase in serum levels of urea, creatinine and urea nitrogen when compared with rats fed on basal diet negative control. Moreover, all nephrotoxic rats supplemented with different levels of ganoderma powder ( 5,10 and $15 \mathrm{~g} / \mathrm{kg}$ diet ) had significant decrease in serum level of urea . creatinine and urea nitrogen when compared with positive control group. This study agreemented with Babu et al., (1995), who reported that minimum dose of cisplatin $(5 \mathrm{mg} / \mathrm{kg}$ body wt, intraperitoneum was sufficient to induce nephrotoxicity in rats. This dose of cisplatin normally used in clinical practice (Somani et al., 2000). Also our results was agreement with Sheena et al., ( 2003 ); Naokikashimoto et al., (2010) and Fernández-Rojas et al., ( 2014 ), they stated that serum creatinine and urea levels were significantly elevated $(P<0.001)$ in the cisplatin-treated animals compared to the normal group ( - ve ) and treatment of animals with methanolic extract of ganoderma lucidum significantly reduced the elevated levels of serum creatinine and urea to almost normal level. In the same line Pillai et al., (2011), reported that oral administration of ganoderma at a dose of $100 \mathrm{mg} / \mathrm{kg}$ body weight prevented increase in urea, creatinine levels, this result suggested the potential therapeutic use of ganoderma to prevent nephrotoxicity caused during cisplatin chemotherapy.

Table ( 4 ) shows that positive control group had significant increase in uric acid and total protein as compared to group of rats fed on basal diet ( - ve ). While, the nephrotoxicity groups supplemented with different levels of ganoderma powder $(5,10$ and $15 \mathrm{~g} / \mathrm{kg}$ diet $)$ showed significant decrease in uric acid and total protein compared with the positive control group. The significant decrease in serum level of uric acid and total protein was shown in the group supplemented with $15 \mathrm{~g} / \mathrm{kg}$ diet when compared with the positive control group and non significant when compared with negative control group.

Table ( 5 ) demonstrate that, rats fed on the basal diet and treated with cisplatin ( positive control group ) had significant decrease in superoxide dismutase, catalase and glutathione peroxidase compared with rats fed on basal diet ( control negative). While groups injected with cisplatin to induce nephrotoxicity and supplemented with different levels of ganoderma powder at ( 5,10 and $15 \mathrm{~g} / \mathrm{kg}$ diet ) had significant increase in superoxide dismutase, catalase and glutathione peroxidase compared with positive control group and non significant changes when compared with negative control group especially groups supplemented with ganoderma powder at ( 10 and $15 \mathrm{~g} / \mathrm{kg}$ diet ). The results agreed with that of Lusania et al., (2000) ; Mora et al., (2003) ; Sheena et al., (2003) ; Alireza et al., (2014) and Zhaoli et al., (2014). They, found that renal CAT and GPX activities were decreased significantly $(P<0.001)$ after administration of cisplatin, while the administration of methanolic extract of ganoderma lucidum to cisplatin treated rats group restored the activites of CAT and GPX and SOD to almost normal level. Also, (Nonaka et al., 2005) reported that ganoderma lucidum is useful in reducing the adverse effects of anti- cancer drugs ( cisplatin ).

Table ( 6 ), indicates that rats fed on basal diet and treated with cisplatin ( positive control) had significant decrease in glutathione (GSH) as compared with rats fed on basal diet ( negative control), and a significant increase in malondialdehyde (MDA) level when compared with negative control group. Our results agreed with Somani et al., ( 2000 ) Alireza et al., ( 2014) ; Fernández-Rojas et al., ( 2014 ) and Zhaoli et al., ( 2014 ), They reported that cisplatin -induced nephrotoxicity by decrease in renal antioxidant defence system and the increase in lipid peroxidation. Furthermore all rats with induced nephrotoxicity and supplemented with different levels of ganoderma powder ( 5,10 and $15 \mathrm{~g} / \mathrm{kg}$ diet ) recorded a significant increase in serum level of glutathione and significant decrease in serum level 


\section{Egypt. J. of Nutrition and Health Vol. 9 No. 1 (2014)}

of malondialdehyde compared to positive control group. These results agreed with (Sheena et al , 2003 ; Alireza et al., 2014 ; Fernández-Rojas et al., 2014 and Zhaoli et al., 2014 ) they found that the renal glutathione ( GSH ) concentration significantly decreased $(P<0.001)$ in cisplatin-treated animals compared to the normal group, indicating the enhanced activity of lipid peroxidation. However, the administration of methanolic extract of ganoderma lucidum to cisplatin treatment rats group elevated the renal glutathione ( GSH ) concentration to the normal level, while the concentration of malondialdehyde (MDA ) as observed, significantly decreased to the normal level compared to cisplatin-treated animals.

From the results obtained, consumption ganoderma lucidum is recommended for nephrotoxic patients, and we encourage foodstuff fortification with ganoderma lucidum since it has therapeutic effect against cisplatin that induced nephrotoxicity and inhibit oxidative stress.

Histopathological examination :

Histopathological examination of liver for rats fed basal diet ( negative control ) showed normal histological structure of the hepatic lobules as shown in ( Fig. 1-A ). The liver of rats injected with cisplatin and fed on basal diet ( positive control) showed cytoplasmic vacuolizations of hepatocytes as shown in ( Fig.1-B). While Fig. (1-C) showed the liver of rats injected with cisplatin and supplemented with ganoderma lucidum at $5 \mathrm{~g} / \mathrm{kg}$ diet showed dilatation of hepatic sinusoids and activation of kupller cells, while the group supplemented with level 2 ( $10 \mathrm{~g} / \mathrm{kg}$ diet $)$ of ganoderma lucidum showed kupller cells activation as shown in Fig. (1-D ). Moreover, Fig. ( 1-E ) showed the liver of group supplemented with level 3 ( $15 \mathrm{~g} / \mathrm{kg}$ diet ) of ganoderma lucidum showed no histopathological changes .

This study showed that the kidneys of the negative control group ( fed on basal diet ) had the normal histological structure of renal parenchyma as shown in ( Fig. 2- A), on the other hand group of rats injected with cisplatin and fed on basal diet (positive control ) showed atrophy of glomerular tuft and distension of bowman's space ( Fig. 2-B ), while the kidneys of rats injected with cisplatin and supplemented with ganoderma lucidum at 5 $\mathrm{g} / \mathrm{kg}$ diet showed congestion of glomerular tuft as shown in Fig. (2- C ). Moreover, Fig. (2- D ) showed the kidneys of rats injected with cisplatin and received level 2 ( $10 \mathrm{~g} / \mathrm{kg}$ diet ) ganoderma lucidum had no histopathological changes. The kidneys of rats injected with cisplatin and received level $3(15 \mathrm{~g} / \mathrm{kg}$ diet $)$ ganoderma lucidum showed no histopathological changes as shown in ( Fig. 2- E).

Ganoderma lucidum (Reishi), are rich in vitamins, fiber, and amino acids and low in fat, cholesterol, and calories. These mushrooms contain a large variety of biologically active polysaccharides with immunostimulatory properties, which contribute to their anticancer effects. Furthermore, other bioactive substances, including triterpenes, proteins, lipids, and phenols, have been identified and characterized in medicinal mushrooms, which are responsible for its therapeutic effects (Sliva, 2004).

Free radicals are known to play an important role in cisplatin-induced nephrotoxicity. The free radicals and reactive oxygen species induce oxidative stress in kidneys (Hannemann and Baumann , 1988 ; Uslu and Bonavida , 1996 and Lusania et al., 2000).

The depletion of GSH can markedly increase the toxicity of cisplatin, probably due to the augmentation of lipid peroxidation ( Sheena et al ., 2003). Cisplatin administration, platinum sulphydryl group complexes formed are taken up by renal cells and stabilized by intracellular GSH for several hours. In case of intracellular GSH depletion, the complexes undergo rapid transformation to reactive metabolites. Thus glutathione depletion results in increased toxicity of cisplatin. Glutathione depletion also results in lipid peroxidation and this seems to be the prime factor that permits lipid peroxidation and impaired antioxidant enzyme activities. These observations support the conclusion that the mechanism of nephrotoxicity in cisplatin-treated rats is related to depletion of antioxidant systems (Ban et al., 1994 ; Lusania et al., 2000 and Ronald et al., 2010). 


\section{Maha M. Essam El-Din and Maha A. El-Mowafy}

The decrease in SOD activity after cisplatin administration might be due to the loss of copper and zinc, which are essential for enzyme activity. Cisplatin has been demonstrated to induce the loss of copper and zinc in the kidneys. The decreased SOD activity is insufficient to scavenge the superoxide anion produced during the normal metabolic process. The superoxide anion can cause initiation and progression of lipid peroxidation ( Sharma , 1985 ; Kerim et al., 2009 ; Alireza et al., 2014 ; Fernández-Rojas et al., 2014 and Zhaoli et al., 2014 ) .

The activity of CAT and GPX is also found to decrease after cisplatin administration. This resulted in the decreased ability of the kidney to scavenge toxic $\mathrm{H}_{2} \mathrm{O}_{2}$ and lipid peroxides (Sheena et al ., 2003). While. the restoration of renal SOD, CAT and GPX activities by treatment with ganoderma lucidum extract capable of protecting the enzymes (Sheena et al ., 2003 and Kerim et al., 2009). Thus, treatment of nephrotoxicity by the ganoderma ( reishi mushroom ) might be directly related to its antioxidant activity.

From the results obtained, an increase of the consumption of ganoderma lucidum is recommended improve nephrotoxicity, and we encourage foodstuff fortification with ganoderma lucidum since it has therapeutic effect against cisplatin that induced nephrotoxicity and inhibit oxidative stress. In addition, nutrition education programs are needed to inform the public about the important role of the ganoderma lucidum ( reishi mushroom ) in a diet. Finally, further studies are needed to examine the effect of ganoderma lucidum on other biological and biochemical parameters as well as in the field of food science.

Table (1):

Effect of Feeding Ganoderma on Feed Intake ( FI), Body Weight Gain ( BWG) and Feed Efficiency Ratio ( FER ) of Rats

\begin{tabular}{|c|c|c|c|}
\hline Groups & FI ( g / day ) & BWG (g/28 days) & FER \\
\hline Negative control & $15.04 \pm 0.30^{a, b}$ & $9.20 \pm 1.10^{a, b}$ & $0.025 \pm 0.04^{a, b}$ \\
\hline Positive control & $10.60 \pm 0.28^{c}$ & $-5.80 \pm 1.00^{c}$ & $-0.022 \pm 0.07^{c}$ \\
\hline Ganoderma at $5 \mathrm{~g} / \mathrm{kg}$ diet & $13.40 \pm 0.33^{\mathrm{b}, \mathrm{c}}$ & $3.60 \pm 1.09^{\mathrm{b}}$ & $0.011 \pm 1.00^{\mathrm{b}}$ \\
\hline Ganoderma at $10 \mathrm{~g} / \mathrm{kg}$ diet & $14.80 \pm 0.59^{\mathrm{a}, \mathrm{b}}$ & $7.20 \pm 1.12^{\mathrm{b}}$ & $0.019 \pm 1.10^{\mathrm{b}}$ \\
\hline Ganoderma at $15 \mathrm{~g} / \mathrm{kg}$ diet & $15.40 \pm 1.00^{\mathrm{a}}$ & $5.00 \pm 0.99^{\mathrm{a}}$ & $0.014 \pm 1.02^{\mathrm{a}}$ \\
\hline
\end{tabular}

Values were expressed as mean $\pm S D$. Values in the same column sharing the same superscript letters are not statistically significant at $P \leq 0.05$. 
Table ( 2 ):

Effect of Feeding Ganoderma on Organs Relative Weight of Rats

\begin{tabular}{|c|c|c|c|}
\hline Groups & $\begin{array}{c}\text { Liver } \\
(\%)\end{array}$ & $\begin{array}{c}\text { Heart } \\
(\%)\end{array}$ & $\begin{array}{c}\text { Kidney } \\
(\%)\end{array}$ \\
\hline Negative control & $3.044 \pm 0.83^{a, b}$ & $0.258 \pm 0.65^{a}$ & $0.538 \pm 0.03^{a}$ \\
\hline Positive control & $3.366 \pm 0.83^{a}$ & $0.306 \pm 0.65^{a}$ & $0.526 \pm 0.02^{a}$ \\
\hline Ganoderma at $5 \mathrm{~g} / \mathrm{kg}$ diet & $2.598 \pm 0.93^{\mathrm{b}, \mathrm{c}}$ & $0.302 \pm 0.65^{\mathrm{a}}$ & $0.574 \pm 0.07^{\mathrm{a}}$ \\
\hline Ganoderma at $10 \mathrm{~g} / \mathrm{kg}$ diet & $2.806 \pm 0.83^{\mathrm{b}, \mathrm{c}}$ & $0.292 \pm 0.65^{\mathrm{a}}$ & $0.542 \pm 0.10^{\mathrm{a}}$ \\
\hline Ganoderma at $15 \mathrm{~g} / \mathrm{kg}$ diet & $2.366 \pm 1.08^{\mathrm{c}}$ & $0.278 \pm 0.41^{\mathrm{a}}$ & $0.556 \pm 0.09^{\mathrm{a}}$ \\
\hline
\end{tabular}

Values were expressed as mean $\pm S D$. Values in the same column sharing the same superscript letters are not statistically significant at $\mathrm{P} \leq 0.05$.

Table ( 3 ):

Effect of Feeding Ganoderma on Serum Levels of Urea, Creatinine and Urea Nitrogen of Rats

\begin{tabular}{|c|c|c|c|}
\hline \multirow{2}{*}{ Groups } & $\begin{array}{c}\text { Urea } \\
(\mathrm{mg} / \mathrm{dl})\end{array}$ & $\begin{array}{c}\text { Creatinine } \\
(\mathrm{mg} / \mathrm{dl})\end{array}$ & $\begin{array}{c}\text { Urea Nitrogen } \\
(\mathrm{mg} / \mathrm{dl})\end{array}$ \\
\cline { 2 - 4 } & Mean $\pm \mathrm{SD}$ & Mean $\pm \mathrm{SD}$ & Mean \pm SD \\
\hline Negative control & $21.80 \pm 2.69^{\mathrm{b}}$ & $1.05 \pm 0.15^{\mathrm{a}}$ & $10.46 \pm 1.40^{\mathrm{a}}$ \\
\hline Positive control & $36.66 \pm 2.00^{\mathrm{a}}$ & $1.46 \pm 0.19^{\mathrm{b}}$ & $17.53 \pm 1.65^{\mathrm{a}}$ \\
\hline Ganoderma at $5 \mathrm{~g} / \mathrm{kg}$ diet & $30.00 \pm 2.93^{\mathrm{a} b \mathrm{~b}}$ & $1.39 \pm 0.35^{\mathrm{a} . \mathrm{b}}$ & $14.66 \pm 0.99^{\mathrm{a} . \mathrm{b}}$ \\
\hline Ganoderma at $10 \mathrm{~g} / \mathrm{kg}$ diet & $28.00 \pm 1.83^{\mathrm{b}}$ & $1.33 \pm 0.26^{\mathrm{a}}$ & $13.00 \pm 1.30^{\mathrm{b}}$ \\
\hline Ganoderma at $15 \mathrm{~g} / \mathrm{kg}$ diet & $22.33 \pm 1.33^{\mathrm{b}}$ & $1.29 \pm 0.95^{\mathrm{a}}$ & $10.90 \pm 1.09^{\mathrm{b}}$ \\
\hline
\end{tabular}

Values were expressed as mean \pm SD. Values in the same column sharing the same superscript letters are not statistically significant at $\mathrm{P} \leq 0.05$. 
Table ( 4 ):

Effect of Feeding Ganoderma on Serum Levels of Uric acid and Total protein of Rats

\begin{tabular}{|c|c|c|}
\hline Groups & $\begin{array}{c}\text { Uric acid } \\
(\mathrm{mg} / \mathrm{dl})\end{array}$ & $\begin{array}{c}\text { Total protein } \\
(\mathrm{mg} / \mathrm{dl})\end{array}$ \\
\hline Negative control & $2.46 \pm 0.37^{\mathrm{c}}$ & $6.60 \pm 0.96^{\mathrm{b}}$ \\
\hline Positive control & $4.43 \pm \cdot .85^{\mathrm{a}}$ & $8.43 \pm 0.82^{\mathrm{a}}$ \\
\hline Ganoderma at $5 \mathrm{~g} / \mathrm{kg}$ diet & $3.90 \pm 0.32^{\mathrm{a}, \mathrm{b}}$ & $7.13 \pm 0.57^{\mathrm{a} . \mathrm{b}}$ \\
\hline Ganoderma at $10 \mathrm{~g} / \mathrm{kg}$ diet & $3.36 \pm 0.48^{\mathrm{a}, \mathrm{b}, \mathrm{c}}$ & $6.63 \pm \cdot, 74^{\mathrm{b}}$ \\
\hline Ganoderma at $15 \mathrm{~g} / \mathrm{kg}$ diet & $3.00 \pm 0.14^{\mathrm{b}, \mathrm{c}}$ & $6.36 \pm 0.74^{\mathrm{b}}$ \\
\hline
\end{tabular}

Values were expressed as mean $\pm S D$. Values in the same column sharing the same superscript letters are not statistically significant at $P \leq 0.05$.

Table ( 5 ):

Effect of Feeding Ganoderma on Serum Levels of Superoxide Dismutase (SOD), Catalase (CAT) and Glutathione Peroxidase (GPX) of Rats

\begin{tabular}{|c|c|c|c|}
\hline Groups & $(\mathrm{SOD})(\mathrm{mmol} / \mathrm{l})$ & $\begin{array}{c}(\mathrm{CAT}) \\
(\mathrm{mg} / \mathrm{dl})\end{array}$ & $\begin{array}{c}(\mathrm{GPX}) \\
(\mathrm{mg} / \mathrm{dl})\end{array}$ \\
\hline Negative control & $94.80 \pm 1.03^{\mathrm{a}}$ & $729.83 \pm 0.96^{\mathrm{a}}$ & $35.94 \pm 1.98^{\mathrm{a}}$ \\
\hline Positive control & $56.51 \pm 1.05^{\mathrm{d}}$ & $308.40 \pm \cdot, 76^{\mathrm{d}}$ & $29.18 \pm 1.00^{\mathrm{b}}$ \\
\hline Ganoderma at $5 \mathrm{~g} / \mathrm{kg}$ diet & $61.63 \pm 1.85^{\mathrm{c}}$ & $453.20 \pm 1.25^{\mathrm{c}}$ & $33.41 \pm 1.70^{\mathrm{a}, \mathrm{b}}$ \\
\hline Ganoderma at $10 \mathrm{~g} / \mathrm{kg}$ diet & $76.41 \pm 1.25^{\mathrm{b}}$ & $461.50 \pm 1.00^{\mathrm{b}}$ & $34.88 \pm 1.10^{\mathrm{a}, \mathrm{b}}$ \\
\hline Ganoderma at $15 \mathrm{~g} / \mathrm{kg}$ diet & $92.42 \pm 1.87^{\mathrm{a}}$ & $726 \pm 1.87 \mathrm{a}$ & $35.41 \pm 1.09^{\mathrm{a}}$ \\
\hline
\end{tabular}

Values were expressed as mean $\pm S D$. Values in the same column sharing the same superscript letters are not statistically significant at $P \leq 0.05$. 
Table 6 :

Effect of Feeding Ganoderma on Serum Levels of Glutathione (GSH) and Malondialdehyde (MDA) of Rats

\begin{tabular}{|c|c|c|}
\hline Groups & $\begin{array}{c}(\mathrm{GSH}) \\
(\mathrm{nmol} / \mathrm{mg})\end{array}$ & $\begin{array}{c}(\mathrm{MDA}) \\
(\mathrm{mg} / \mathrm{dl})\end{array}$ \\
\hline Negative control & $9.15 \pm 0.57^{\mathrm{a}}$ & $18.00 \pm 1.59^{\mathrm{b}}$ \\
\hline Positive control & $4.79 \pm 0.77^{\mathrm{c}}$ & $25.81 \pm 2.00^{\mathrm{a}}$ \\
\hline Ganoderma at $5 \mathrm{~g} / \mathrm{kg}$ diet & $5.76 \pm 1.03^{\mathrm{b} . \mathrm{c}}$ & $21.92 \pm 1.84^{\mathrm{a}, \mathrm{b}}$ \\
\hline Ganoderma at $10 \mathrm{~g} / \mathrm{kg}$ diet & $7.52 \pm 0.60^{\mathrm{a}, \mathrm{b}}$ & $18.71 \pm 1.35^{\mathrm{b}}$ \\
\hline Ganoderma at $15 \mathrm{~g} / \mathrm{kg}$ diet & $8.49 \pm 0.84^{\mathrm{a}}$ & $\mathrm{b}$ \\
\hline
\end{tabular}

Values were expressed as mean $\pm S D$. Values in the same column sharing the same superscript letters are not statistically significant at $\mathrm{P} \leq 0.05$. 
Maha M. Essam El-Din and Maha A. El-Mowafy

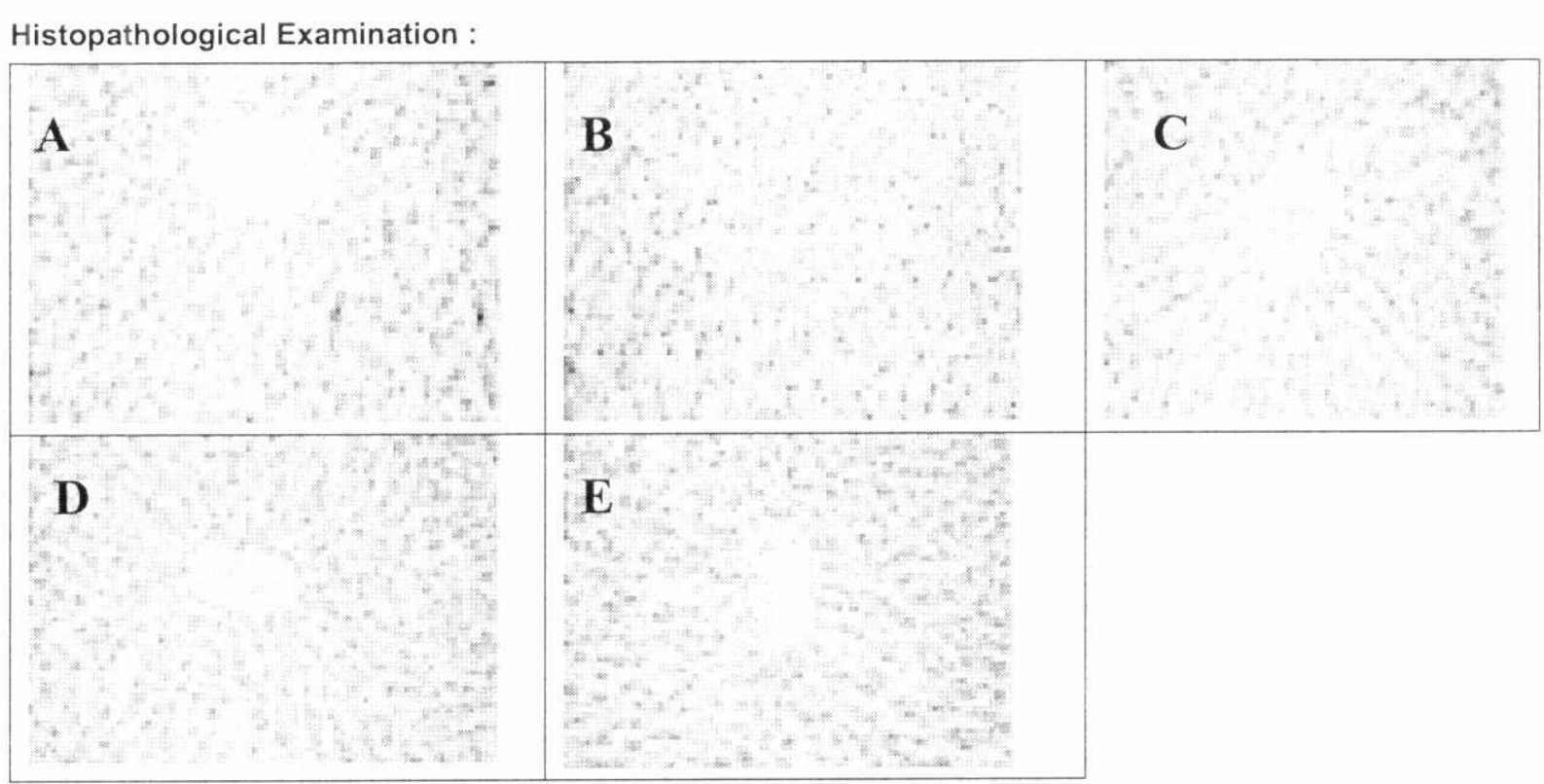

Fig. 1: Histopathological changes detected in the liver of (A) negative control, (B) positive control, (C) $5 \mathrm{~g} / \mathrm{kg}$ diet of Ganoderma lucidum, (D) $10 \mathrm{~g} / \mathrm{kg}$ diet of Ganoderma lucidum , (E) $15 \mathrm{~g} / \mathrm{kg}$ diet of Ganoderma lucidum ( H and $E \times 400)$.

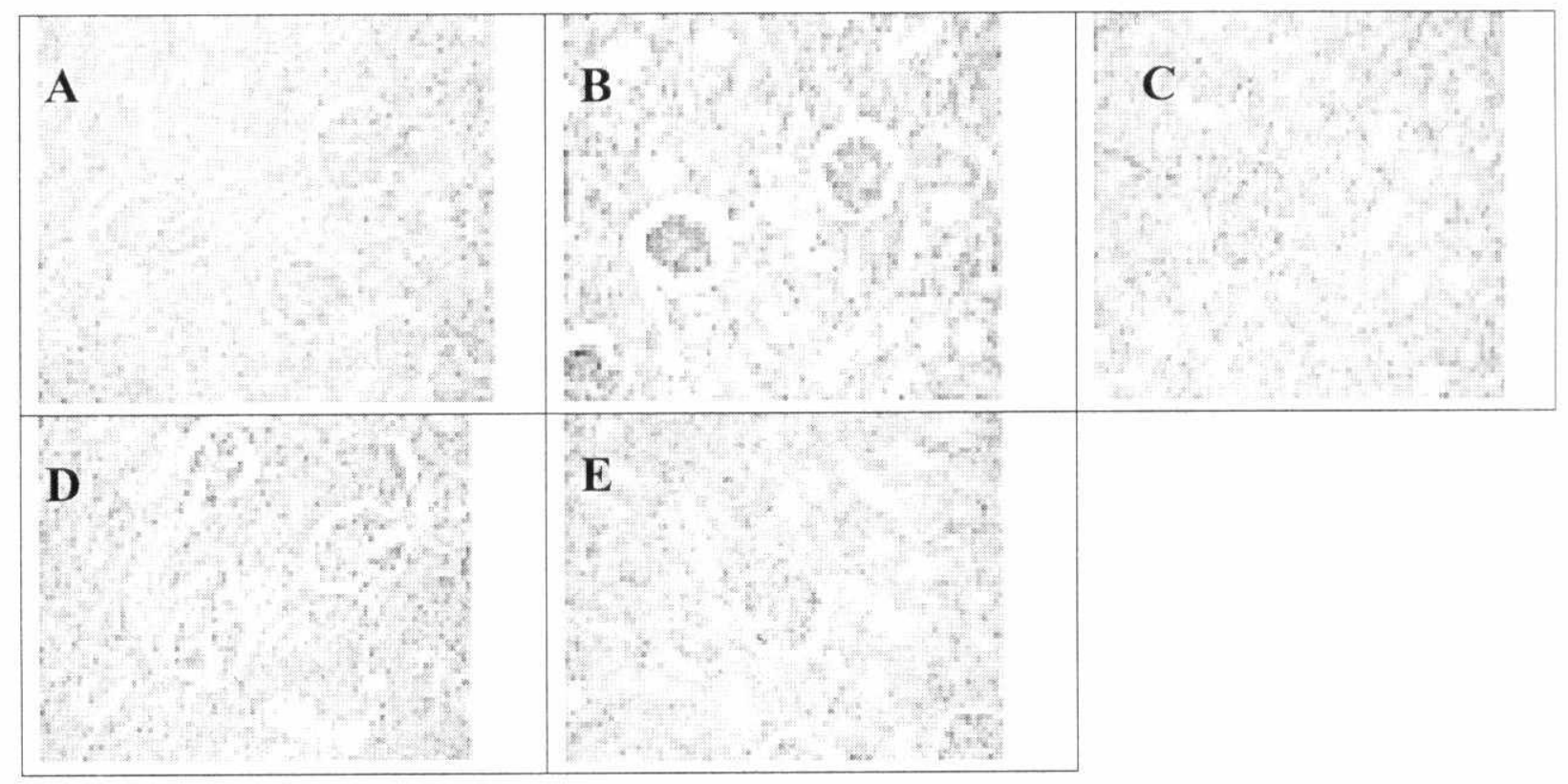

Fig. 2: Histopathological changes detected in the kidneys of (A) negative control, (B) positive control, (C) $5 \mathrm{~g} / \mathrm{kg}$ diet of Ganoderma lucidum , (D) $10 \mathrm{~g} / \mathrm{kg}$ diet of Ganoderma lucidum , (E) $15 \mathrm{~g} / \mathrm{kg}$ diet of Ganoderma lucidum (H and $E \times 400$ ). 


\section{References}

Alireza S. ; Somayeh S. ; Zohreh R. ; Amir D. Farnoush D.; Alireza S. and Behzad E. ( 2014 ) :

Normobaric hyperoxia preconditioning ameliorates cisplatin nephrotoxicity. Renal Failure. February 2014 , Vol. 36 , No. 1 , Pages 5-8

Babu E. ; Gopalkrishnan V. ; Sriganth N. ; Gopalkrishnan R. and Sakthisekhran D. ( 1995 ) :

Cisplatin induced nephrotoxicity and the modulating effect of glutathione ester. Mol. Cell Biochem., 144 : 7-11.

Ban M. ; Hettich D. and Huguet N. ( 1994 ):

Nephrotoxicity mechanism of cis-platinum (II) diamine dichloride in mice. Toxicol. Lett., 71: 161-168.

Beers R. and Sizer I. ( 1952 ) :

A spectrophotometric method for measuring the breakdown of hydrogen peroxide by catalase. J. Biol. Chem , 195: $133-140$.

Bodenner D. ; Dedon P. ; Keng P. ; Katz J. and Borch R. ( 1986 ) :

Selective protection against cisplatin induced toxicity in kidney, gut and bone marrow DDTC. Cancer Res., 46 : 2751-2755.

Bojana B.; Marin B. and Zhang J . ( 2007 ) :

Ganoderma Lucidum and its pharmaceutically active compounds. Biotech Ann Rev. ; 13 : 265-301.

Brod J. and Sirota J. ( 1980 ) :

In Practical Clinical Biochemistry, William Heinman Medical Books Ltd, London, vol. 1 : pp. 456-460.

Cohen S. ; Rousseau M . and Robinson E . (2000) :

Therapeutic use of selected herbs. Holist. Nurs . Pract. 14 ( 3$): 59-68$.

Fenglin Li Z. Z. ( 2011 ) :

Antihyperglycemic Effect of Ganoderma Lucidum Polysaccharides on Streptozotocin-Induced Diabetic Mice , Int. J. Mol. Sci. ; 12(9): 6135-6145.

Fernández-Rojas B. ; Omar N. ; Rogelio H.; Mario N. and Sara H. (2014):

C-Phycocyanin prevents cisplatin-induced nephrotoxicity through inhibition of oxidative stress. Food Funct., 1 Jan 2014 , Advance Article.

Hafemann, D. G., Sunde, R. A. and Houestra, W. G. ( 1974 ) :

Effect of dietary selenium on erythrocyte and liver glutathione peroxidase in the rat. J. Nutr., 104: 580-584.

Hamers F. ; Gispen W. and Neijt, J. ( 1991 ):

Neurotoxic side effects of cisplatin. Eur. J. Cancer, $27: 372-376$.

Hannemann, J. and Baumann, K. ( 1988 ) : Cisplatin-induced lipid peroxidation and decrease of gluconeogenesis in rat kidney cortex: differential effects and radical scavengers. Toxicology, 51: 119-132. 
Henry R. ; Sobel C. and Kim J. (1957) :

A modified carbonate phosphotungstate method for the determination of uric acid and comparison with the spectrophoto-metric uricase method. Am J Clin Pathol . 1957;28:152 - 160

Jong S. and Birmingham J. ( 1992 ):

Medicinal benefits of the mushroom Ganoderma. Adv Appl Microbiol. 37: 101-134.

Kenneth J. ( 1992 ) :

Ancient herb for modern times. Sylvan Press, 1992.

Kerim C. ; Ali K. ; Abdulkadir Y. ; Yildiray K. ; Akar K. ; Mustafa K. and Salim B. ( 2009 ) :

Protective effect of L-carnitine against cisplatin-induced liver and kidney oxidant injury in rats . Central European Journal of Medicine Volume 4, Number 2 : 184-191.

Lingzhi ( 1986 ) :

In Pharmacology and Application of Chinese Materia Medica, Vol. I. Chang HM and But RPH, eds. World Scientific: Singapore, 642.

Lusania M. ; Greggi A. Joana D. and Maria D. ( 2000 ):

Protective effects of vitamin c against cisplatin-inducednephrotoxicity and lipid peroxidation in adult rats: a dosedependent study. Pharmacological Research , 41 (4) : Pages 405-411.

Marshell, M. H.; Fingerhurt, B. and Miller, H. ( 1980 ) :

In Practical Clinical Biochemistry (eds Varley, H. et al.), William Heinman Medical Books Ltd, London, vol. 1: pp. 478-480.

McCord J. and Fridovich I. ( 1969 ):

Superoxide dismutase, an enzymatic function for erythrocuprein . J. Biol. Chem.,244: 6049-6055.

Mora L. ; Antunes L. ; Francescato H. and Bianchi M. ( 2003 ) :

The effects of oral glutamine on cisplatin-induced nephrotoxicity in rats. Pharmacological Research : the Official Journal of the Italian Pharmacological Society . 47(6): 517-522 .

Moron M. ; Depierre J. and Mannervik B. ( 1979 ) :

Levels of glutathione and glutathione S-transferase activities in rat lung and liver. Biochem. Biophys. Acta, $582: 67-78$.

Naokikashimoto O.; Satomiishii I.; Yukimyojin M. and Hiromitsu E. ( 2010 ):

A water-soluble extract from cultured medium of Ganoderma lucidum (Reishi) mycelia attenuates the small intestinal injury induced by anti-cancer drugs, Oncol Lett. January; 1(1): 63-68.

Nonaka Y.; Ishibashi H.; Nakai M.; Shibata H.; Kiso Y. and Abe S. ( 2005 ) :

Soothing effect of Ganoderma lucidum antlered form on cyclophosphamide-induced adverse reaction. Jpn. J. Cancer Chemother (in Japanese); 32 : 1586-1588. 


\section{Egypt. J. of Nutrition and Health Vol. 9 No. 1 (2014)}

Ohkawa H.; Ohishi N. and Yagi K. ( 1979 ):

Assay for lipid peroxide in animal tissues by thiobarbituric acid reaction. Ann. Biochem., 95: 351-358.

Pillai T.G. ; John M. and Sara T.G. ( 2011 ) :

Prevention of cisplatin induced nephrotoxicity by terpenes isolated from Ganoderma lucidum occurring in Southern Parts of India. Exp Toxicol Pathol. Jan;63(1-2):157-160

Reeves P. ; Nielsen F. and Fahmy G. ( 1993 ) :

Purified diets for laboratory rodents : Final report of the American Institute of Nutrition ad Hoc writing committee on the reformulation of the AIN-76 a rodent diet. J . Nurtr ., 123: $1939-1951$.

Ronald P. M. ; Raghu K. T. ; Ganesan R. and William B. ( 2010 ) :

Mechanisms of Cisplatin Nephrotoxicity. Toxins , 2: 2490-2518.

SAS. ( 2006 ) :

Statistical Analysis System, SAS User's Guide : Statistics. SAS Institute Inc. Editors, Cary, NC.

Sharma R. ( 1985 ) :

Interactions of cisplatin with cellular zinc and copper in liver and kidney tissues. Pharmacol. Res. Commun., 17: 197-206.

Sheena N. ; Ajith T. and Janardhanan K. ( 2003 ) :

Prevention of nephrotoxicity induced by the anticancer drug cisplatin, using Ganoderma lucidum, a medicinal mushroom occurring in South India Current Science, Vol. 85, No. $4: 478-482$.

Sliva D. ( 2004 ) :

Cellular and physiological effects of Ganoderma lucidum (Reishi). Med Chem Oct;4(8) : 873-879 .

Somani S. ; Husain K. and Whitworth C. ( 2000 ):

Dose-dependent protection by lipoic acid against cisplatin induced nephrotoxicity in rats: Antioxidant defence system. Pharmacol. Toxicol., $86: 234-241$.

\section{Stanislaus C. ( 1995$)$ :}

Lingzhi Medicine of Kings. New Editions Health World, June : 38-41.

\section{Stavinoha W. ( 1990 ):}

Study of the anti-inflammatory activity of Ganoderma lucidum. Presented at the Third Academic/Industry Joint Conference (AIJC), Sapporo, Japan .

Uslu, R. and Bonavida B. ( 1996 ) :

Involvement of the mitochondrion respiratory chain in the synergy achieved by treatment of human ovarian carcinoma cell lines with tumour necrosis factor-alpha and cis-diammine dichloroplatinum (II). Cancer, 77: 725- 732 .

Wasson R.G. ( 1968 ) :

Divine mushroom of immortality. Harcourt, Brace, Jovanovich, Los Angeles : 80-93. 


\section{Maha M. Essam El-Din and Maha A. El-Mowafy}

\section{Zenk S .; Shaver J. ; Fox. P. and Chavez N.(2001):}

Use of herbal therapies among midlife Mexican women. Health Care Woman Int . 22(6) : 585-597.

Zhaoli G. ; Guangyi L. ; Zhao H. ; Xing L. and Xiangdong Y.( 2014 ) :

Grape seed proanthocyanidin extract protects from cisplatin-induced nephrotoxicity by inhibiting endoplasmic reticulum stress-induced apoptosis. Molecular Medicine Reports : January 3, 2014 . Volume 9 Issue 3 Pages: 801-807

\section{كفاءه الجانوديرما ( Ganoderma lucidum ) ضد التسمم الكلوى المحدث بواسطه السبسبلاتين فى ذكور الفئران البالغه .}

\section{مها محمد عصام الدين 1 - مها عبد المطلب الموافى 2}

1 قنم التغذيه و علوم الاطعمه ، كليه الإتصاد المنزلى ، جامعه حلوان ، القاهره ، مصر. - - ' اخصائيه تخذية، مديرية الثربية و التعليم، الغربيه، مصر .

\section{الملخص العربى}

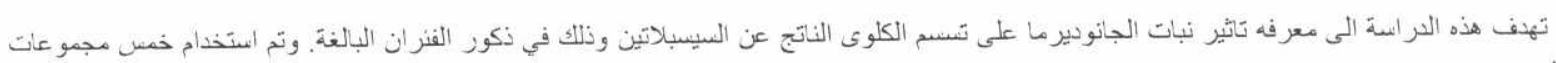

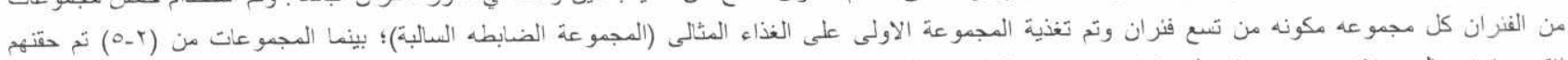

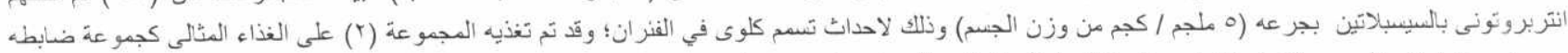

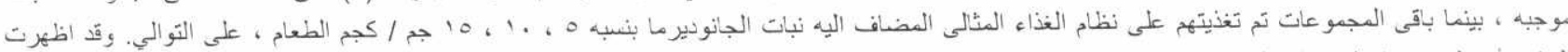

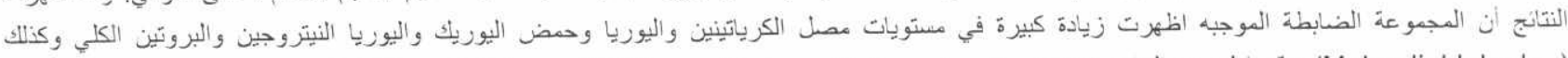
Superoxide Dismutase (SOD) , Catalase (CAT) وقد اظهرت النتين (Malondialdahyde )

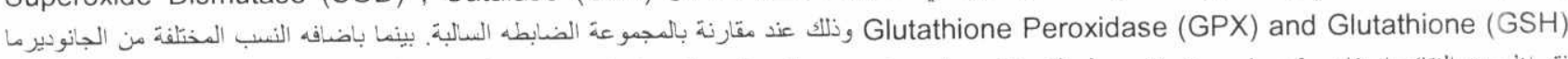

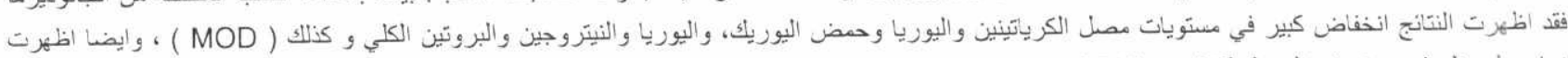

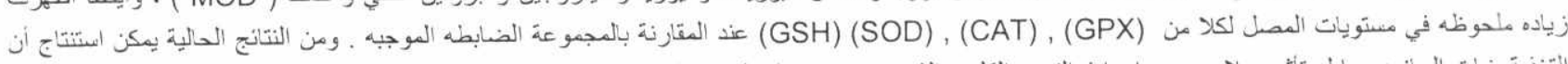

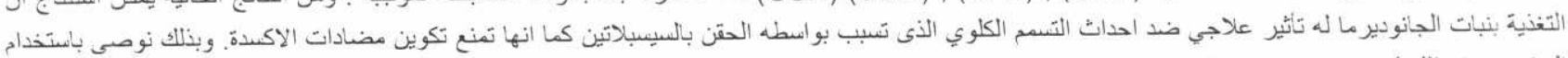
الجانو دير ما وزللك لعلاج حالات تسمع الكلى. الكلمات الرينيسة: ذكور الفنران ، سيسبلاتين، التسمح الكلوى ، الفظر ريثي، جانوديرما، وظانف الكلى، مضادات الأكسدة. 